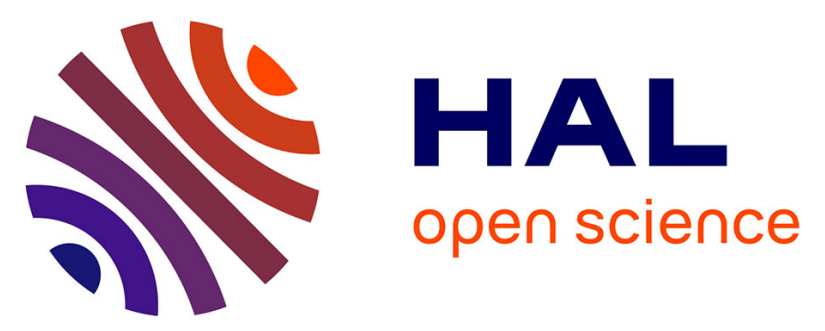

\title{
Role of the OPG/RANK/RANKL triad in calcifications of the atheromatous plaques: Comparison between carotid and femoral beds.
}

Marie-Françoise Heymann, Fanny Herisson, Jean-Michel Davaine, Céline Charrier, Séverine Battaglia, Norbert Passuti, Gilles Lambert, Yann Gouëffic, Dominique Heymann

\section{To cite this version:}

Marie-Françoise Heymann, Fanny Herisson, Jean-Michel Davaine, Céline Charrier, Séverine Battaglia, et al.. Role of the OPG/RANK/RANKL triad in calcifications of the atheromatous plaques: Comparison between carotid and femoral beds.: OPG/RANK/RANKL and atherosclerosis. Cytokine, 2012, 58 (2), pp.300-6. 10.1016/j.cyto.2012.02.004 . inserm-00692423

\section{HAL Id: inserm-00692423 https://www.hal.inserm.fr/inserm-00692423}

Submitted on 30 Apr 2012

HAL is a multi-disciplinary open access archive for the deposit and dissemination of scientific research documents, whether they are published or not. The documents may come from teaching and research institutions in France or abroad, or from public or private research centers.
L'archive ouverte pluridisciplinaire HAL, est destinée au dépôt et à la diffusion de documents scientifiques de niveau recherche, publiés ou non, émanant des établissements d'enseignement et de recherche français ou étrangers, des laboratoires publics ou privés. 
Figure 1
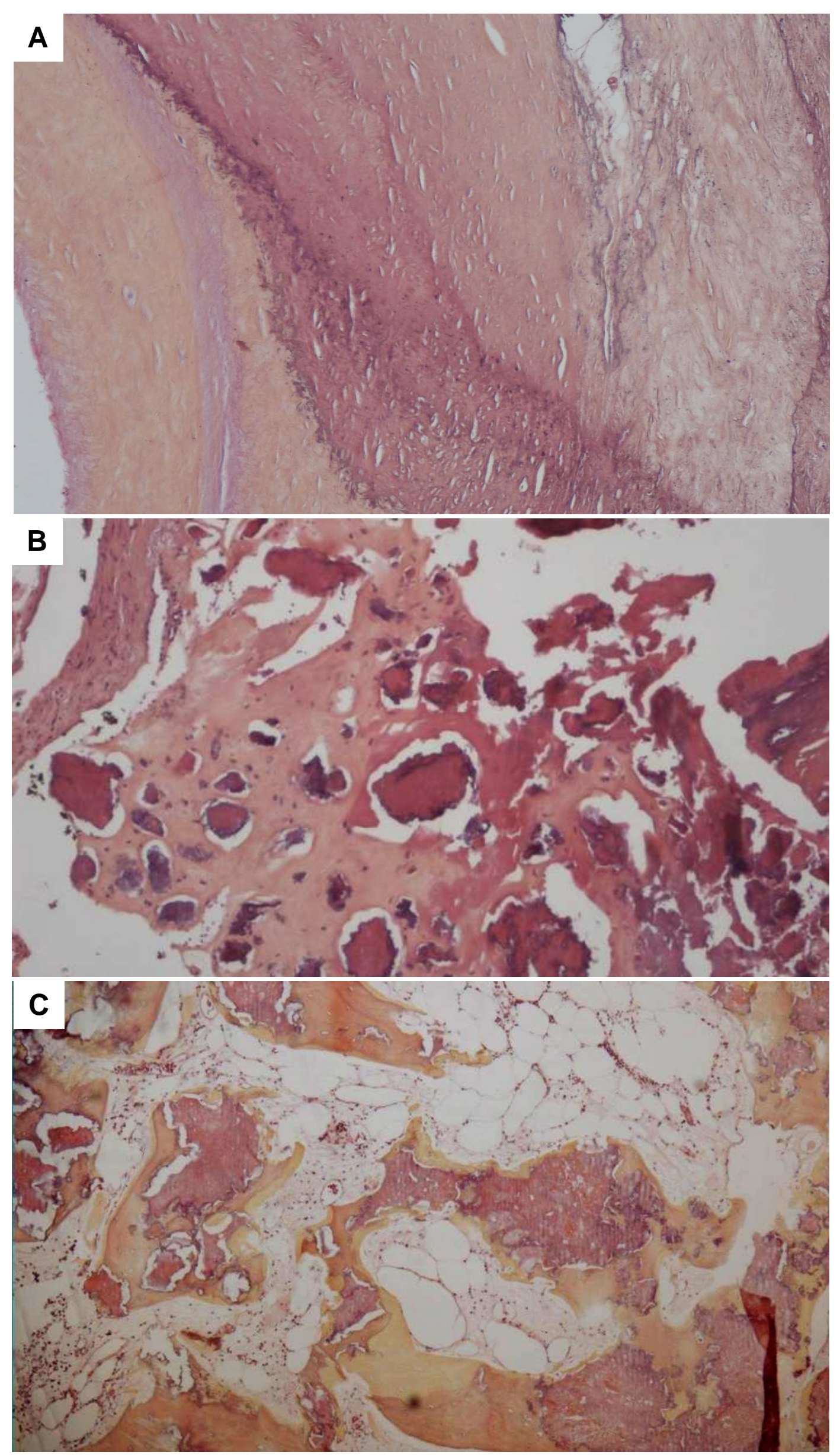